\title{
ORIGEN Y REVALORIZACION DE LOS PUEBLOS DEL ARROZ EN LA CUENCA BAJA DEL CEBOLLATI
}

\author{
Autor: Susana Martínez Benia \\ Universidad de la República, Uruguay \\ Director Dr. Arq. Mercedes Medina, Co-Director: Dr. Arq. Joaquín Sabaté Bel \\ smartinezbenia@gmail.com
}

\section{RESUMEN}

La cuenca del Cebollatí, al este del Uruguay, forma parte de la cuenca binacional de la Laguna Merim que comparten Uruguay y Brasil. Es un territorio, con fuertes valores ambientales cuya estructuración está caracterizada por la geografía. Un territorio despoblado hasta que se instalan sociedades agropecuarias privadas que desencadenan procesos de ocupación que cambian la matriz productiva, social y económica del área.

La investigación, con el propósito de generar conocimiento para utilizar los recursos culturales, se centra en la sistematización de la estructura territorial producto del cultivo del arroz que genera formas de ocupación y estrategias de uso que forjaron un nuevo espacio con identidad física, económica y cultural propia.

Culmina con reflexiones propensas a mejorar la calidad de vida de los ambientes rurales de los puebles del arroz vinculando el patrimonio cultural con las redes de espacios naturales y desafíos relacionados con el ámbito público y privado.

Palabras clave: pueblos del arroz, Cuenca del Cebollatí, paisaje cultural

\section{ABSTRACT}

The Cebollatí basin, east of Uruguay, is part of the Merim Lagoon basin shared between Uruguay and Brazil. It is a territory, with strong environmental values whose structuring is characterized by geography. A depopulated territory until private agricultural societies are established that unleash occupation processes that change the productive, social and economic matrix of the area.

The research, with the purpose of generating knowledge to use cultural resources, focuses on the systematization of the territorial structure resulting from the cultivation of rice that generates forms of occupation and use strategies that formed a new space with physical, economic and cultural identity own. It culminates with reflections prone to improve the quality of life of the rural environments of the rice villages by linking the cultural heritage with the networks of natural spaces and challenges related to the public and private sphere.

Keywords: rice villages, Cebollatí Basin, cultural landscape 


\section{PRESENTACION}

En el Este Uruguayo, en la frontera con Brasil, se encuentra la Laguna Merín, una de las mayores reservas de agua dulce del planeta que conforma en su cuenca una importante reserva ecológica.

La cuenca hidrográfica binacional ocupa el $18 \%$ del territorio nacional, y tiene como principales afluentes entre otros los ríos Cebollatí y Tacuarí Esta porción del territorio uruguayo, comienza a estructurarse a partir del siglo XVIII, cuando comienzan la apropiación privada de la tierra en el este de la entonces Banda Oriental. En un primer momento se instalan establecimientos ganaderos, pero es recién en el siglo XX, que se desencadena un proceso de ocupación del territorio fruto de la organización productiva de la explotación de arroz. Su avance, provoca cambios que implican importantes transformaciones. En consecuencia, el territorio resultante, revela las huellas de estas intervenciones asociadas a prácticas individuales y grupales. En el conviven un patrimonio arqueológico -cerritos de indios-, que apelan a las raíces y a los primeros habitantes de nuestro territorio, un paisaje natural de llanuras, esteros, lagunas y montes naturales, desconocido para muchos y el paisaje cultural generado por el cultivo e industrialización del arroz, cuyo avance pone en riesgo al primero.

Se trata de investigar con el propósito de traducir los patrones de comportamiento promoviendo el rescate de la identidad histórico-cultura, con el objetivo de fundir la historia cultural con la voluntad de proyectar el futuro y contribuir a la generación de conocimiento para crear espacios de identidad y alentar a la concientización y a la puesta en valor de los recursos naturales y culturales.

El trabajo se aborda desde la perspectiva territorial, soporte físico más construcción histórica, al cual nos aproximamos en tres niveles: el histórico, las transformaciones actuales y el contexto de la interpretación.

Las hipótesis de la investigación apuntan al reconocimiento de las potencialidades del territorio de la Cuenca del Cebollatí.

La primera sostiene que el soporte geográfico es sustancial en la estructuración del paisaje cultural del arroz. Para ello se realizan aproximaciones desde el proceso de ocupación y estructuración, reconociendo la inexorable dependencia de la geografía en la transformación del territorio.

La segunda señala que los pueblos del arroz tienen patrones similares, que constituyen su principal valor. Para su verificación se analiza el patrimonio rural, el sistema de asentamiento y sus patrones, profundizando en el estudio de casos.

La tercera afirma que el cultivo del arroz habilitó formas de ocupación y estrategias de usos que generaron un espacio geográfico con identidad física, económica y cultural propia. En este supuesto se profundiza en el estudio del patrimonio rural y natural y en las modalidades de uso explicando e interpretando el territorio de la Cuenca del Cebollatí.

En este artículo se expone la estructuración del territorio en la Cuenca del Cebollatí, como resultado del cultivo de arroz, que a través de la historia, los intereses políticos, sociales y económicos que hicieron posible el fenómeno explican la arquitectura, el urbanismo y el paisaje de los pueblos del arroz.

\section{2 ÁREA DE ESTUDIO Y CONCEPTOS GENERALES}

El área de estudio, se localiza en un vasto territorio, al este de Uruguay y del continente americano, sobre la Laguna Merín, una de las mayores reservas de agua dulce del planeta, que conforma una unidad territorial, una cuenca binacional compartida entre Uruguay-Brasil,. Está limitada hacia el este por el Océano Atlántico y hacia el interior del territorio por la divisoria de las aguas. Gran parte de esa superficie está compuesta por tierras de relieve ondulado que rodean una gran llanura. Se comunica al norte y a través del canal de San Gonzalo con la Laguna de los Patos situada en el estado de Rio Grande do Sul conformando una vía navegable que se vincula con el océano Atlántico. Esta hidrovía que se extiende por la Laguna de los Patos ha sido empleada a lo largo de la historia. Si bien, la Corona Española en el Siglo XVIII visualizó la importancia estratégica y las potencialidades de ese territorio, es recién en la segunda mitad del Siglo XX, en la década de los 60, que se constituyó una Comisión Mixta entre Uruguay y Brasil para estudiar el aprovechamiento integral de la Cuenca de la Laguna Merim.

La dimensión administrativa del sector uruguayo abarca varias departamentos donde se desarrollan, un conjunto de ecosistemas complejos que se destacan por las bellezas escénicas y paisajísticas y actúan como reguladores naturales de la escorrentía fluvial en la cuenca baja 

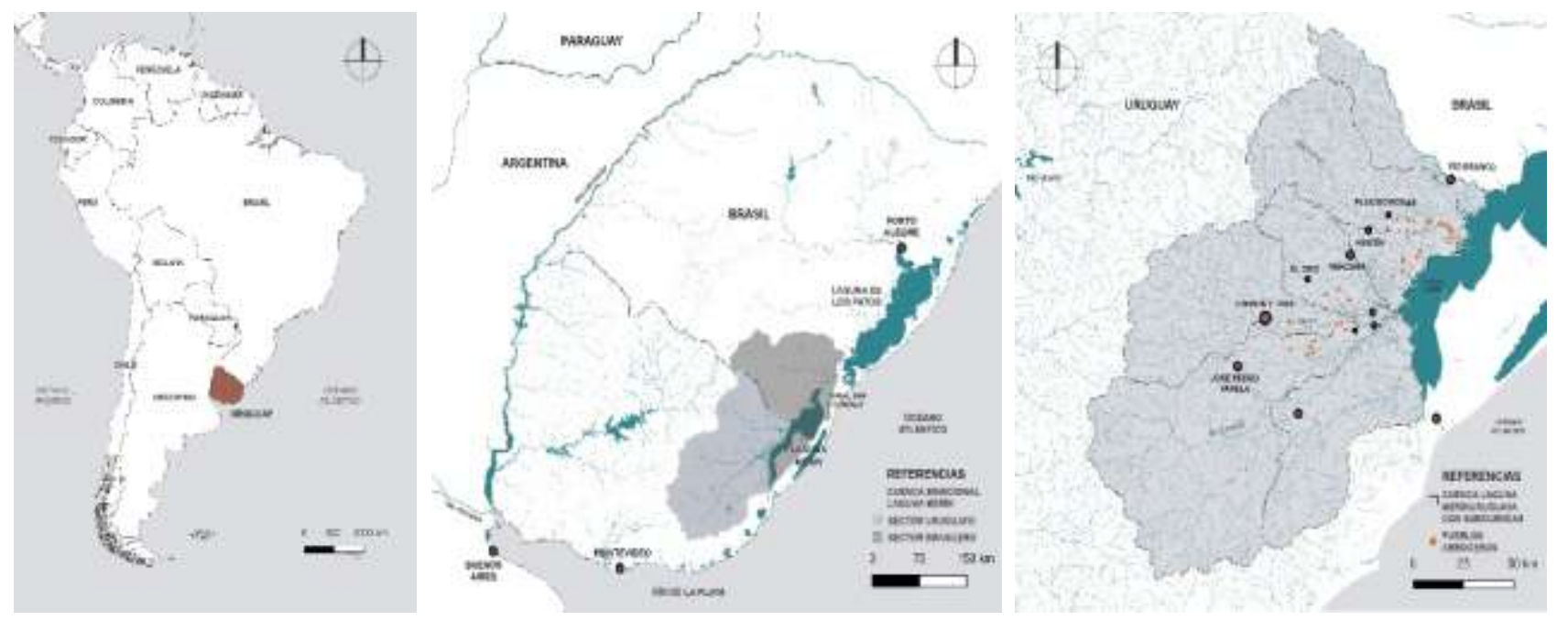

Localización del área de estudio.

Elaboración propia sobre plano de cuencas de la Dirección Nacional de Aguas y Saneamiento.

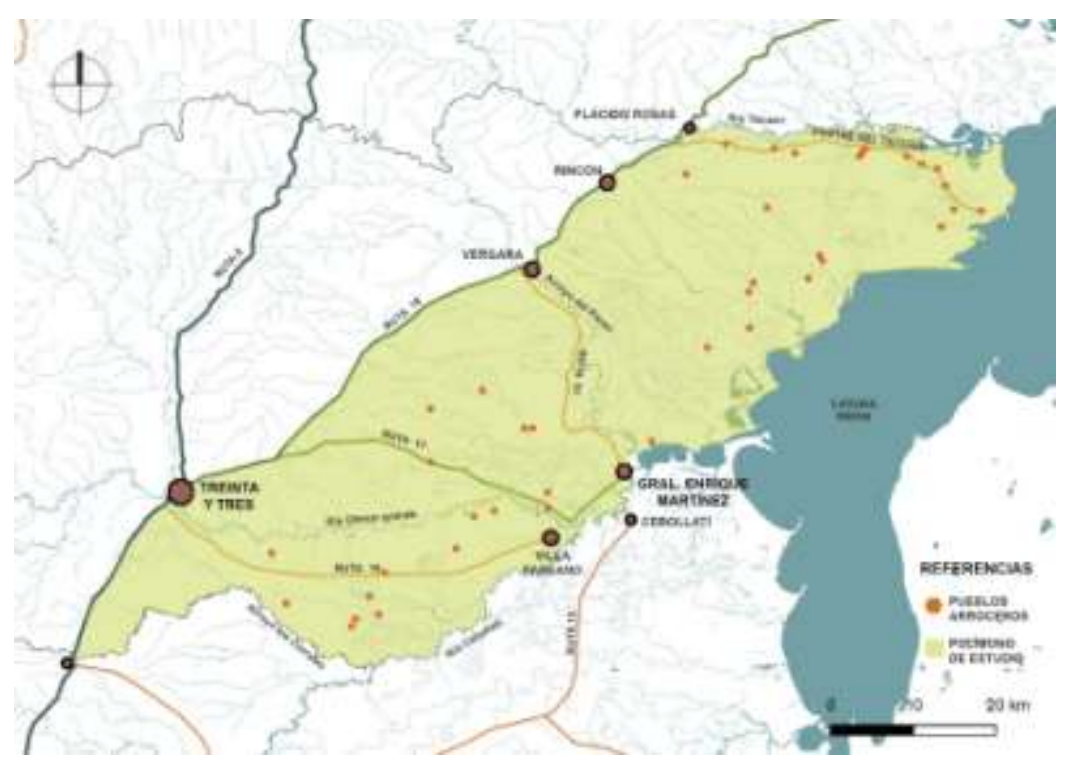

Delimitación del ámbito territorial de estudio.

Elaboración propia sobre cartografía del Instituto Geográfico Militar

El área de estudio, ubicada en el departamento de Treinta y Tres, es representativa de lo que ocurre en la zona, tiene una extensión aproximada a 1/3 del departamento, forma parte de los Humedales del Este y está delimitada por el arroyo los Corrales, el Río Cebollatí, laguna Merim, Rio Tacuarí y R18 y R8.

Para poder explicar la imagen del territorio de la Cuenca Baja del Cebollatí, es imprescindible indagar en su forma, en la interacción del hombre con el medio físico y las huellas tangibles e intangibles que han sido parte de proceso. Comprender como se ha generado este paisaje a partir de la combinación de elementos físicos y antropológicos que en relación interdependiente, generaron un conjunto único y en permanente evolución, permitirá entender la construcción de identidad de ese territorio cuyas transformaciones más importantes surgen con la instalación de Sociedades agropecuarias dedicadas a la explotación agrícola ganadera.

Para entender la evolución del concepto de paisaje cultural nos remitimos a fines del Siglo XIX a escritos de historiadores y geógrafos alemanes ( $F$. Ratzel y Vidal de la Blaché). Pero el término, comienza a definirse en el Siglo XX a través del legado de C. Sauer (1925) que lo explica como el resultado de un grupo social sobre el paisaje natural. Analiza las transformaciones del paisaje natural por la acción del ser humano y estudia la relación cambiante hombre-naturaleza a la vez que J. B. Jackson en la década del 50, reivindica el valor de los paisajes culturales y genera una nueva conciencia sobre los entornos cotidianos, expresando su confianza innata en la capacidad de personas de pocos recursos de hacer cambios 
significativos en su entorno. A través de este legado, que entiende al territorio como construcción humana, se define el paisaje cultural como el registro del hombre sobre el territorio, un palimpsesto (Corboz, 2001), un texto que se puede escribir y reescribir, y que a través de una mirada interescalar, se podrá comprender e interpretar como una síntesis "basada en la vida y el trabajo acumulado sobre un espacio" (Prada, 2010)

Estas reflexiones nos ayudan a entender la evolución del término paisaje cultural en ámbitos académicos y a encontrar las claves para interpretar el paisaje de los pueblos del arroz a través de la revalorización de los ambientes del trabajo y las relaciones del hombre y el territorio. A través de esta mirada sobre los paisajes transformados tenemos la oportunidad de describir y explicar el territorio de la Cuenca Baja del Cebollatí.

Por último, este marco de referencia lo resume la definición de Sabaté de paisaje cultural como ámbito geográfico asociado a un evento, a una actividad o personaje histórico que contiene por tanto valores estéticos como culturales. En este entendido, se trata de revitalizar el patrimonio del trabajo de los pueblos arroceros, vinculados a la red de espacios naturales como fundamento de un nuevo desarrollo local.

Como método de análisis se opta por reconocer la estructura física del territorio, la diversidad y la riqueza de matices en el uso del suelo, registrar las transformaciones y las tensiones dominantes en un contexto que si bien es la producción arrocera y ganadera quien lidera el desarrollo del territorio existen nichos de prácticas productivas que pueden asociarse.

Se seleccionaron los elementos más representativos del territorio y se localizaron y representaron gráficamente sus componentes para contar con una información integrada de todos los factores intervinientes y reconocer su imagen actual e interpretar el paisaje a través de las condicionantes, la problemática y las singularidades de los elementos del medio. Se trata de identificar, observar e investigar esas huellas. Comprenderlas, es una oportunidad de transformación.

\section{EI TERRITORIO DE LA CUENCA BAJA DEL CEBOLLATÍ.}

Con la finalidad de sistematizar la estructura territorial producto del cultivo de arroz y poner en valor los recursos patrimoniales, nos aproximamos en tres niveles: el histórico, el de los procesos ocurridos, las transformaciones actuales y el contexto de la interpretación.

En la primera mitad del siglo XX, la instalación del cultivo de arroz en el este del país provocó un proceso de importantes transformaciones. La organización productiva de la explotación, dio origen a los pueblos arroceros que se han desarrollado como constelaciones convergentes en nodos calificados de servicios de segundo y tercer nivel. En su enorme extensión, el territorio de la Cuenca del Cebollatí, reúne la triple dimensión: productiva, social y ambiental, resultado de un proceso y un producto de prácticas individuales y grupales, en el que conviven un patrimonio arqueológico, un paisaje natural de llanuras, esteros, lagunas y montes naturales, y el paisaje cultural generado por el cultivo e industrialización del arroz.

Se genera un paisaje único y en permanente evolución donde se combinan elementos físicos y antropológicos que presentan configuraciones reconocibles, mosaico de situaciones diferentes; topografía, usos del suelo, vegetación de naturalezas diversas, a veces fragmentadas espacialmente por la agricultura y vías de conexión. Se trata de una zona con potencial destacado, en la cual la producción de arroz convive con otros recursos aún inexplotados.

Al visitar el territorio de la Cuenca Baja del Cebollatí nos encontramos con una gran planicie, con bañados y esteros, arroyos, cañadas, obras de drenaje y riego y cursos de agua mayores que se anuncian por la presencia del monte nativo, que en épocas de lluvia son parcialmente inundadas por las precipitaciones y poblados distribuidos a un lado y otro de los caminos rurales que conectan la red de pueblos arroceros.

\subsection{El Paisaje natural}

Para el estudio de la dimensión natural, que caracteriza el paisaje percibido, se analiza el paisaje total, que identifica los componentes que condicionan usos y ocupación.

En la Cuenca de la Laguna Merín el paisaje natural está constituido por diferentes matrices: llanuras altas que rodean las llanuras bajas que bordean los cursos de agua y las lagunas, llanuras bajas o bañados donde se forman diversos tipos de humedales de escaso escurrimiento, ríos y arroyos en cuyas márgenes crece el monte ribereño y llanuras lagunares que bordean el espejo de agua de la laguna. 

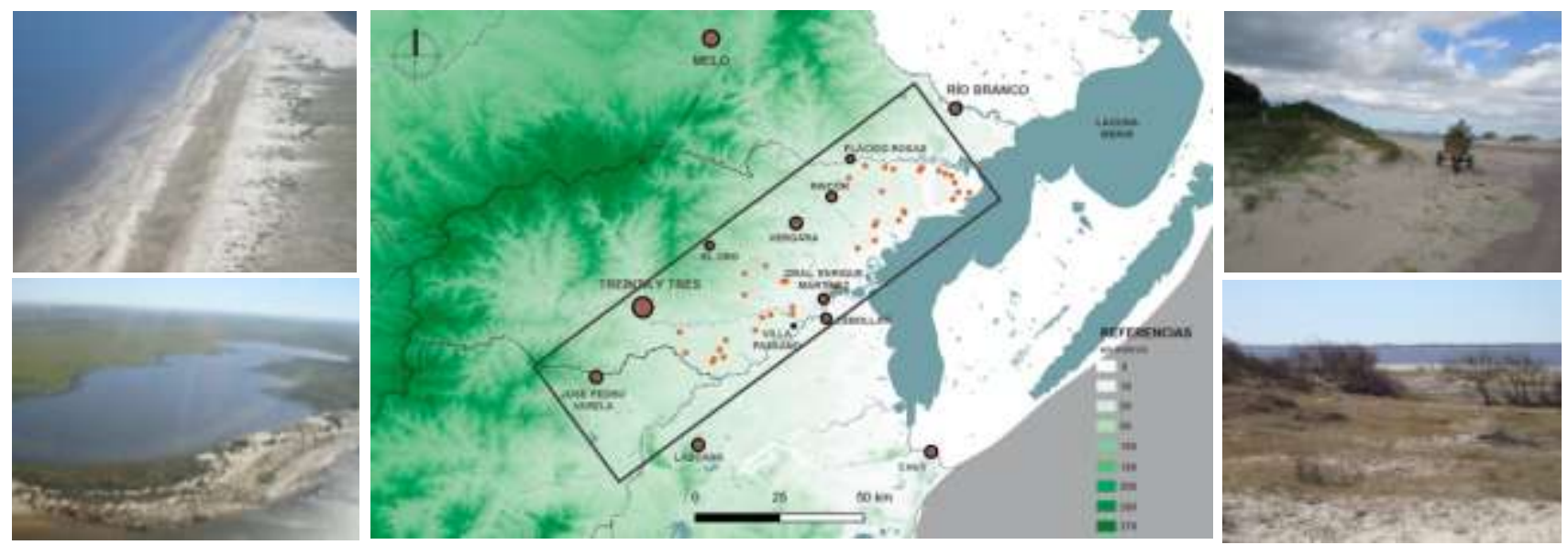

\section{Orografia}

Elaboración propia sobre cartografía del Servicio Geográfico Militar, Dirección Nacional de Aguas e Infraestructura de Datos Espaciales Imágenes de la Laguna Merim de la autora

\subsection{El Paisaje cultural}

Desde la dimensión cultural se analiza la estructura soporte, el sistema de asentamiento de los pueblos del arroz y la vinculación entre ellos y con localidades cercanas. .El sistema estructural de la Cuenca Baja del Cebollatí es el resultado de un proceso de transformación donde se configuran elementos de identificación.

El territorio rural tiene una lógica que se comprende al realizar el análisis desde el urbanismo, al considerar el territorio un objeto construido relacionado con la historia de las comunidades que lo habitan, genera un paisaje que resulta de la relación hombre-territorio, naturaleza-cultura

La construcción de este territorio ha estado impregnada de un sentido utilitarista y funcional: los establecimientos surgen en función del trabajo por lo tanto en su mayoría se localizan al borde de las arterias de comunicación. Si bien la superficie ocupada por los asentamientos urbanos es baja, han generado impactos de importancia vinculados a la infraestructura y los servicios.

El territorio donde se localizan los pueblos del arroz cuenta con un paisaje antropizado, producto del cultivo, particular y atractivo, donde los aspectos culturales y naturales se combinan. La dimensión social y cultural se evidencia en la modificación de las formas y en las huellas trazadas. Para entenderlo, se describen las infraestructuras -rutas, caminos, ferrocarril, obras hidráulicas- que posibilitan la instalación del cultivo y usos y ocupación del suelo que dan cuenta de la relación del hombre-territorio.

Es un territorio que promueve interés por los valores agroecológicos, productivos, hidráulicos y etnográficos. El valor patrimonial reside en el conjunto de piezas organizadas con un agro sistema que modela y subyace a la formación, redes de elementos de interés hidráulico, etnográfico (represas, canales, poblados, caminos, etc.) y arquitectónico.

\subsubsection{Caminos de tierra}

La red vial, conformada por vías de comunicación terrestre clasificadas por jerarquías, permite la accesibilidad al lugar, transformándose en un sistema que permite el flujo de bienes y personas.

Las rutas principales de la Cuenca del Cebollatí, conectadas a rutas y caminos departamentales, hacen posible la conectividad con los centros poblados y establecimientos rurales de la zona. La estructura soporte de este territorio comprende el eje que conecta la capital del país con la frontera brasileña, corredor nacional e internacional de transporte carretero, la rutas nacionales y departamentales, arterias secundarias nominadas por la toponimia local y caminería terciaria que unen los pueblos de la cuenca arrocera y conectan con los campos de cultivo. El camino rural comunica puntos del territorio donde se proponen y disponen campos, casas y pueblos. Su trazado es el resultado de la actividad humana que determina funciones y usos. Se desarrolla de manera homogénea, en la mayoría de los caso sin considerar las características del terreno. La urbanidad del camino está dada por ser el elemento canalizador por el cual se relacionan y desplazan los habitantes del lugar y se transporta la producción 

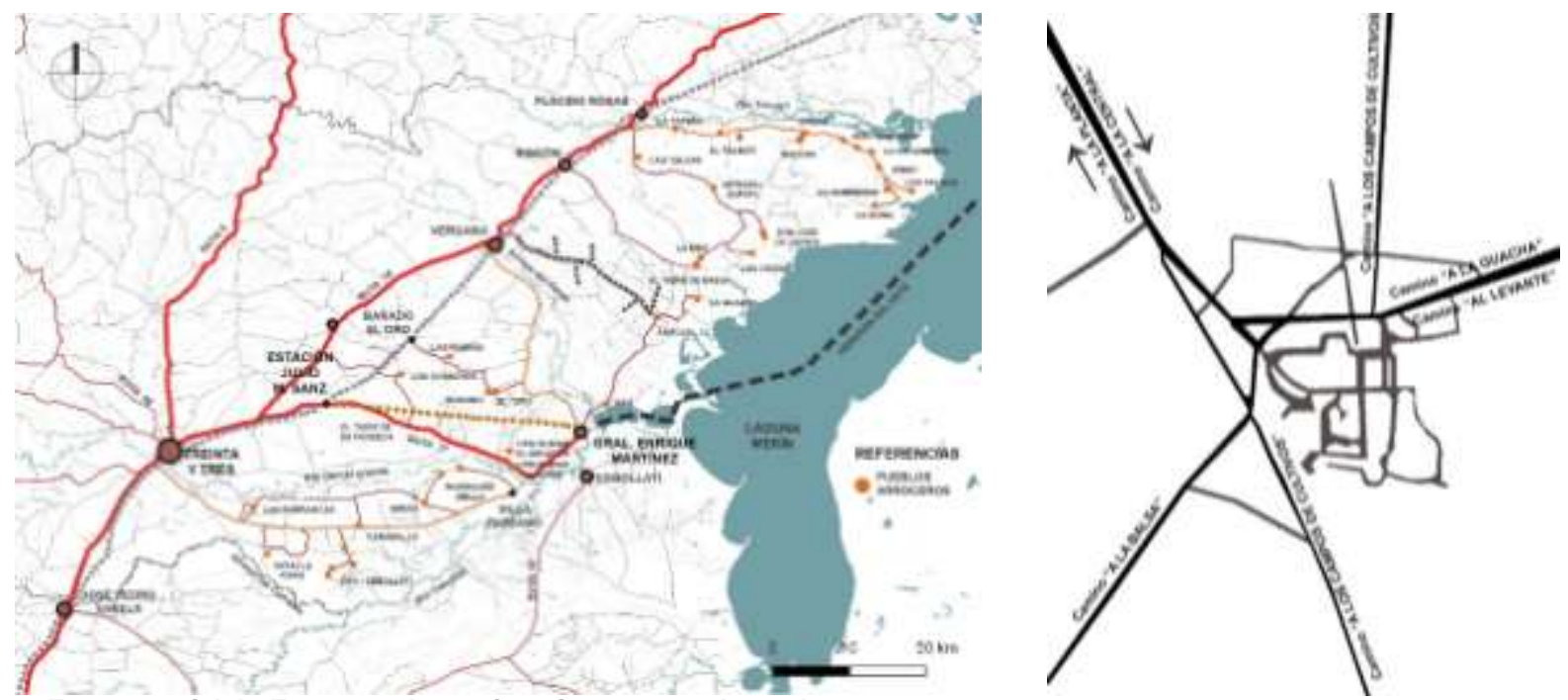

a. Esquema vial b. Esquema de caminos internos en Arrozal 33.

a. Elaboración propia sobre datos de Infraestructura de datos espaciales, Conjunto de datos provisorios (CDP).

b. Elaboración propia en base a imagen de GoogleEarth.

\subsubsection{Ferrocarril}

La red ferroviaria uruguaya, trazada en el siglo XIX por los ingleses, a principios del siglo XX, amplia varios tramos entre ellos en 1934, el de Treinta y Tres hasta Río Branco en la frontera con Brasil.

Alegando promover la producción arrocera, el estado cede los materiales a Arrozal 33 para la ejecución y de una línea privada que une el la red principal en el km 393, donde se ubicaba el Depósito de arroz con la Central, el pueblo, de $26 \mathrm{~km}$ de trocha angosta y también los materiales para una red portátil de $24 \mathrm{~km}$ que se instalaba previo a los trabajos de cosecha, hasta los sectores de diferentes chacras en las cuales se rotaba el cultivo.

Cuando el servicio ferroviario se unifica bajo administración estatal, a mediados de siglo el sistema entra en un proceso de estancamiento por las dificultades para el mantenimiento de vías y renovación de material rodante. La red portátil deja de funcionar en la década del 70 y el tramo fijo en los 80 .

Si bien el cometido principal del ferrocarril fue promover el desarrollo agrícola ganadero, comercial y turístico a través de la conexión áreas productivas-ciudad- puerto, contribuyó a la relación entre el medio urbano y el medio rural.

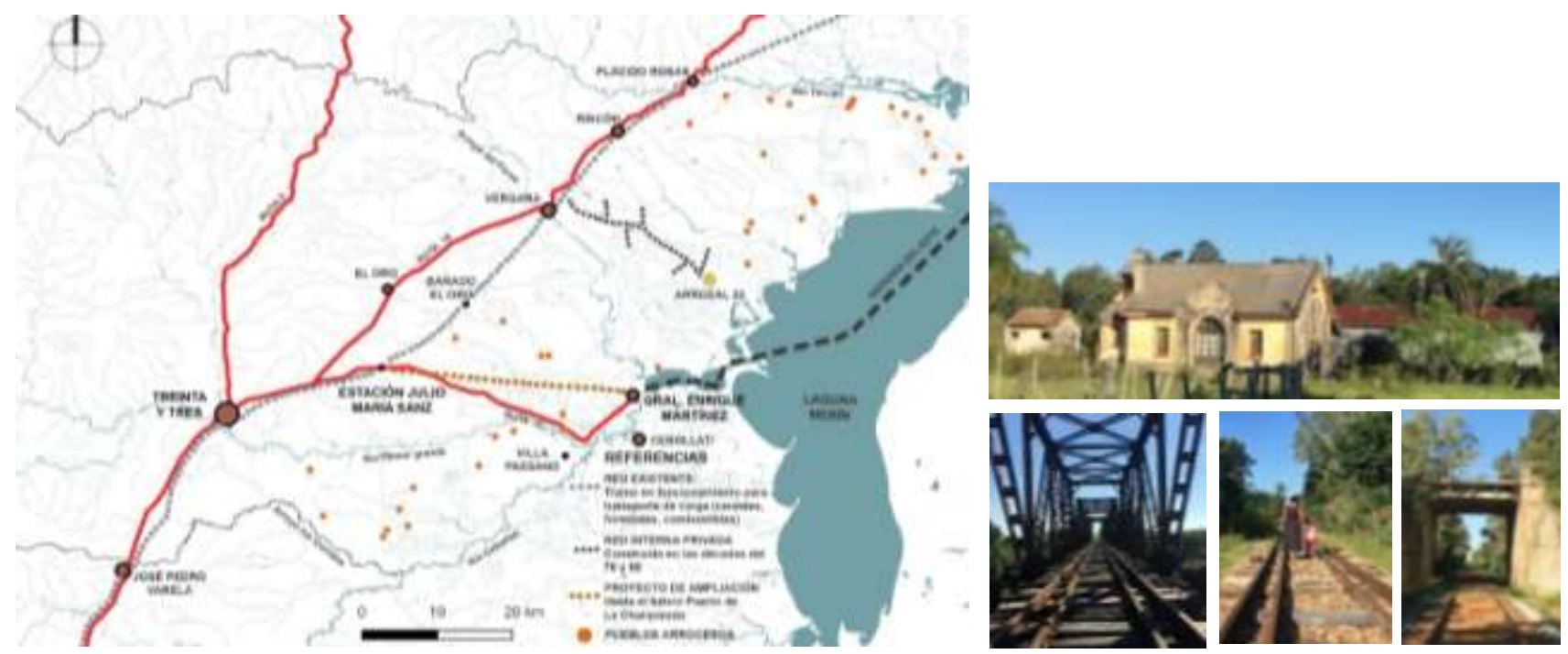

Figura xxx. Esquema ferroviario

Elaboración propia sobre datos de Infraestructura de datos espaciales, Conjunto de datos provisorios (CDP). Huellas del Territorio, equipamiento ferroviario, imágenes de la autora

En la actualidad, está en etapa de proyecto la ampliación de un ramal desde Julio María Sanz hasta la proyectada terminal de Cargas de La Charqueada. Es posible imaginar, que si este emprendimiento se lleva a cabo el transporte ferroviario se revitalizará y será utilizado además para el envío de la producción de 
arroz, madera y soja a Brasil a través de la navegación por el Río Cebollatí, Laguna Merín y Laguna de los Patos, estableciendo un sistema intermodal en el transporte de mercaderías. Numerosas huellas dan cuenta de la importancia de este medio; las estaciones en muchos casos abandonados; los magníficos puentes, las áreas de maniobras, los tanques de agua, las señalizaciones de los pasos a nivel que se repiten en el territorio como huellas de la conexión campo-ciudad

\subsubsection{Caminos de agua}

La red hidrográfica se presenta densa. El riego de arroz estructura el paisaje y junto con los cursos de agua se alternan con la caminería en la construcción y en la organización de las distintas áreas del territorio rural. La densa red de canales principales y secundarios se constituye en la infraestructura de sofisticados sistemas de riego en una gran planicie de suelo poco permeable, que junto con el almacenaje- diques, represas- se convierten en un sistema con fuerza organizadora.

Los ríos y arroyos que desembocan en la Laguna Merín provocan, inundaciones frecuentes por los desbordes, que ocasionalmente afectan al sistema productivo agrícola ganadero pero que ejercen un papel importante en el funcionamiento de los humedales.

En los cursos de agua principales, para permitir mejor conectividad entre localidades cercanas se ofrecen servicios de balsas y boteros, a la vez que el proyecto para la construcción de una terminal de Cargas sobre el Río Cebollatí en la Charqueada, reactivaría la Hidrovía del Este y permitiría un mayor flujo de mercadería entre Brasil y Uruguay a través de la integración en un transporte multimodal.
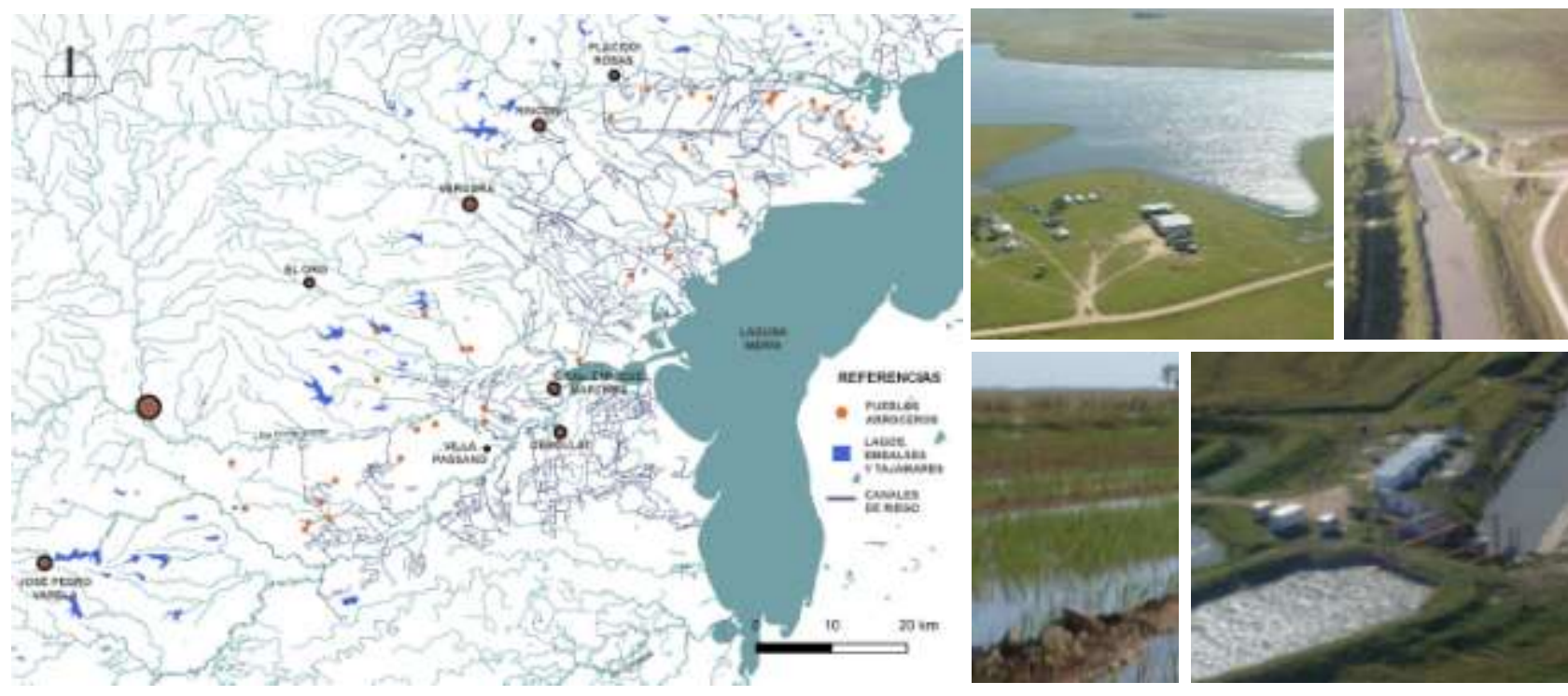

Figura 28. Caminos de agua. Canales de riego.

Elaboración propia sobre datos de Infraestructura de datos espaciales, Conjunto de datos provisorios (CDP). Imágenes de la autora.
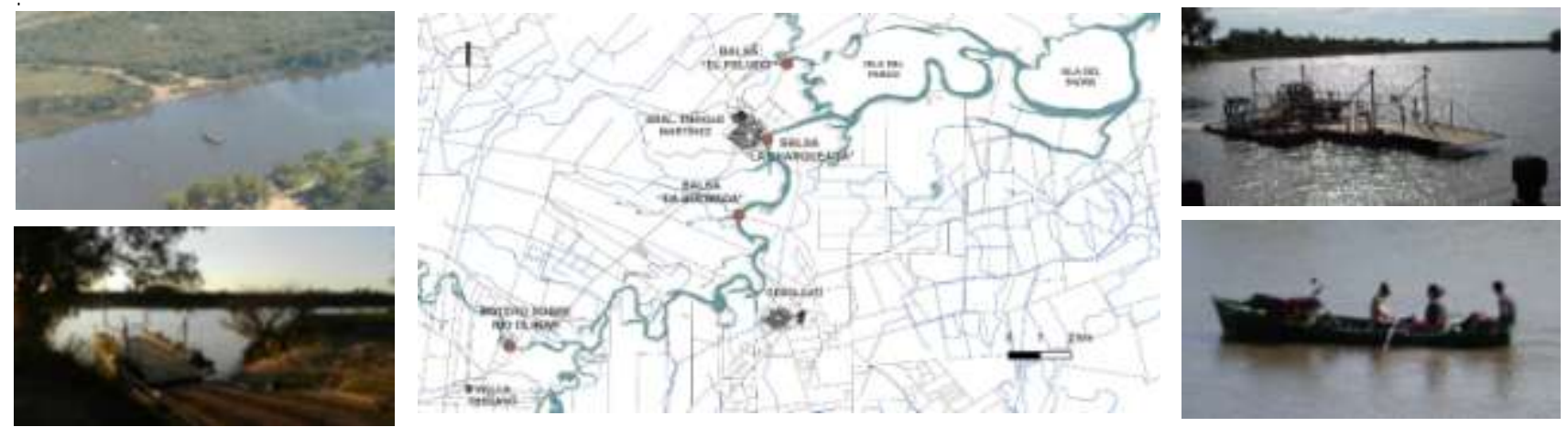

Balsas sobre el Cebollatí y el Parao.

Elaboración propia sobre datos de Infraestructura de datos espaciales, Conjunto de datos provisorios (CDP), Dirección General de Hidrografía, Ministerio de Transporte y Obras Públicas, datos de visita de campo. Fotos de la autora 


\subsubsection{Usos y ocupación}

En el territorio de la Cuenca del Cebollati, se explica un patrimonio "rurbano" (rural+urbano) compuesto por elementos naturales y áreas productivas para la expansión del sistema arrocero-ganadero. El territorio se construye según lógicas productivas, en una topografía e hidrología que han condicionado su ocupación. El cultivo del arroz con importante nivel de desarrollo tecnológico, transforma y estructura el territorio

El uso y la ocupación del suelo permiten determinar áreas específicas: praderas para uso ganadero con pequeños montes artificiales localizados en las zonas altas, para abrigo y sombra del ganado, chacras de cultivos arroceros con presencia de importantes obras de infraestructura, en menores superficies cultivos de secano y población nucleada, en un sistema urbano de varios niveles, vinculado por una red de infraestructura que lo relaciona y permite transitarlo en distintos ritmos.

Se ocupa el territorio con un fin utilitario y funcional en el que se construyen territorialidades en diferentes escenarios: enclaves urbanos emplazadas estratégicamente en torno a las vías de comunicación y al recurso hídrico, enclaves productivos compuestos por viviendas de trabajadores e instalaciones de apoyo a la producción, distribuidos en el territorio estrechamente vinculados al área de cultivo y a la red vial y localización de población dispersa que habita en instalaciones rurales asociadas a la producción ganadera.

El territorio de la Cuenca del Cebollatí, se estructuró con dos lógicas diferentes, la rural y la urbana. Mientras que el trazado rural es más geográfico, con economía de formas, práctico, aunque también con mayor debilidad en los agentes sociales, el trazado urbano, determinado por las funciones territoriales, es más geométrico y artificioso condicionado social, económica y culturalmente por sus orígenes.

$Y$ es en estos procesos complejos en la estructuración del territorio donde se encuentran las claves para interpretar el paisaje de los pueblos del arroz.
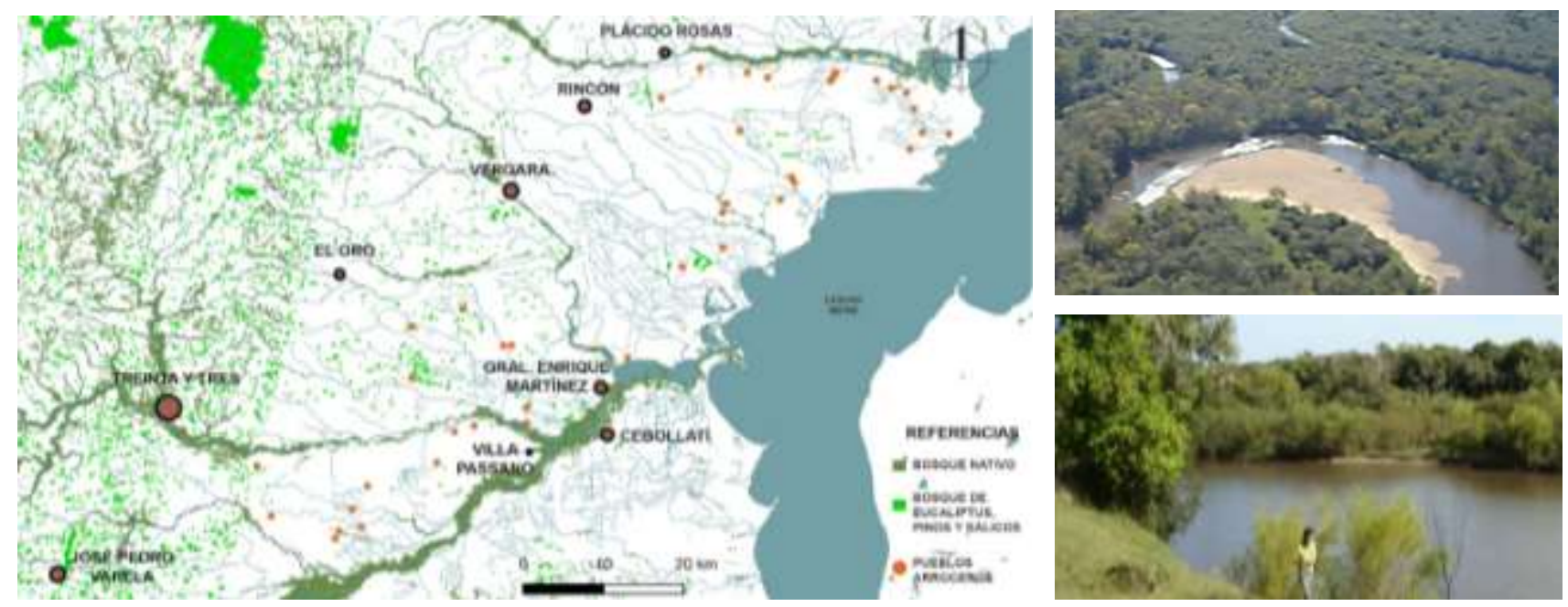

Monte nativo y artificial.

Elaboración propia sobre datos de Infraestructura de datos espaciales, Conjunto de datos provisorios (CDP). Fotos de la autora

\section{Población nucleada}

La distancia a la capital del país, la cercanía con Brasil y la barrera geográfica contribuyó al aislamiento de la zona. Con la extensión de la vía de ferrocarril desde Treinta y tres hasta Río Branco en la frontera con Brasil, comienza el proceso de ocupación del territorio que se acelera a partir de 1960. Si bien, la población es dispersa, el espacio se ordena en una serie de centros poblados de diferente envergadura. Se generan sistemas urbanos que vinculan centros poblados mayores entre sí y con localidades complementarias en las que se conforman pares urbanos a la vez que relaciona los establecimientos ganaderos y enclaves productivos- pueblos arroceros- que surgen con el cultivo de arroz. 

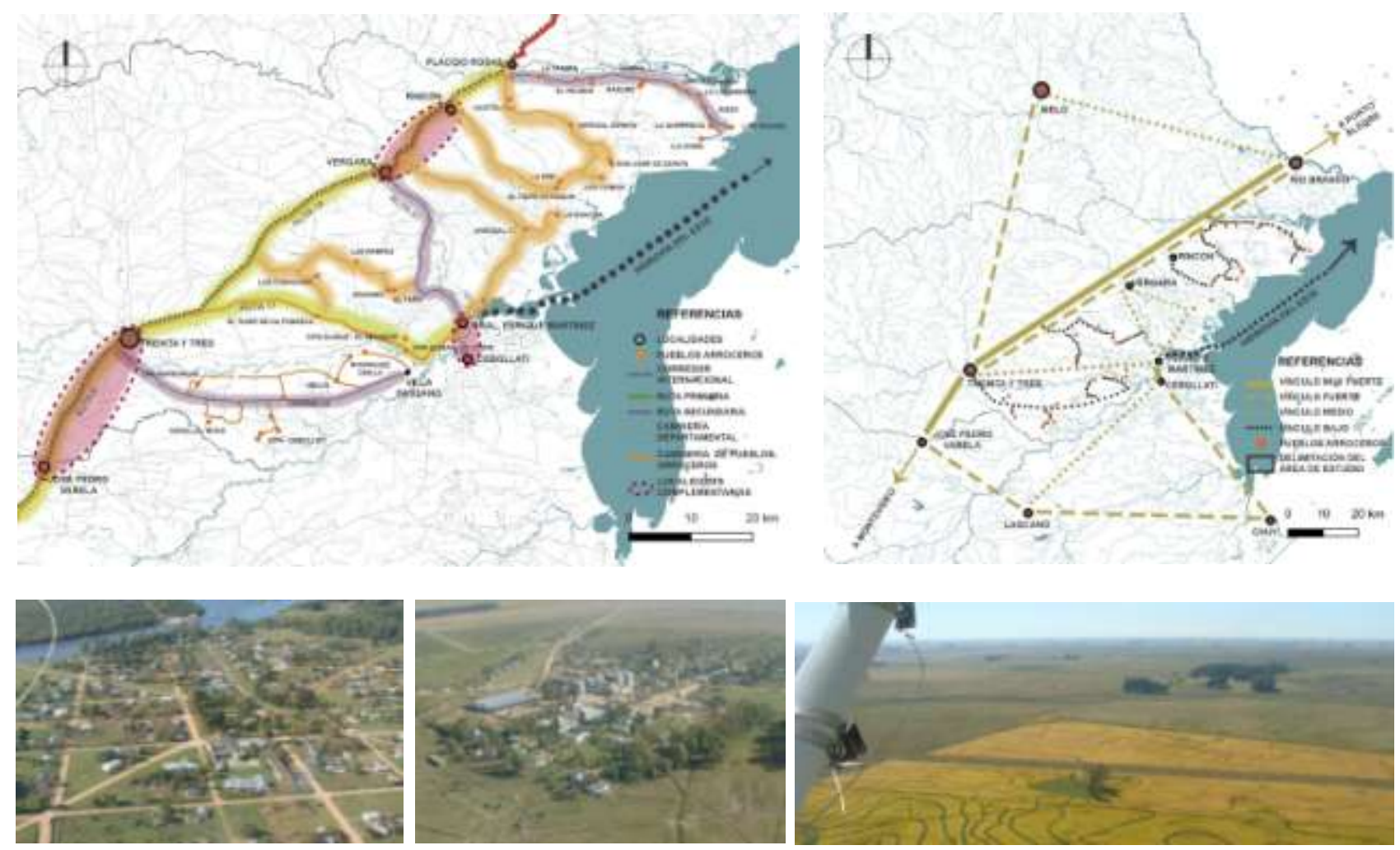

\section{Sistemas urbanos y vínculos}

Elaboración propia sobre datos de Infraestructura de datos espaciales, Conjunto de datos provisorios (CDP

Imágenes aéreas La Charqueada y Arrozal 33 y campo de cultivo, Fotos de la autora

\section{LA CONSTRUCCIÓN DEL TERRITORIO DE LA CUENCA DEL CEBOLLATÍ}

\subsection{Estructuración histórica}

Con el fin de abordar la construcción del territorio de la cuenca de la Laguna Merín, Cuenca del Cebollatí, se visualizaron principalmente tres cortes históricos.

Antes del descubrimiento de América, la Banda Oriental estaba habitada por pueblos nómades sin asentamientos permanentes ni trazas circulatorias. El legado material de estos pueblos, en la Cuenca de la Laguna Merim, se restringe a estructuras prehistóricas "Cerritos de indios", asociados a tierras bajas, localizadas en zona de bañados inundables, que presentan buena e inter visibilidad en el conjunto del paisaje, mientras que el patrimonio intangible de estas comunidades con visiones auténticamente americanas se transforma en pilar de identidad de todos los tiempos, relacionando el coraje y espíritu libertario de los charrúas... con la constricción al trabajo y "el mate" de los guaraníes.

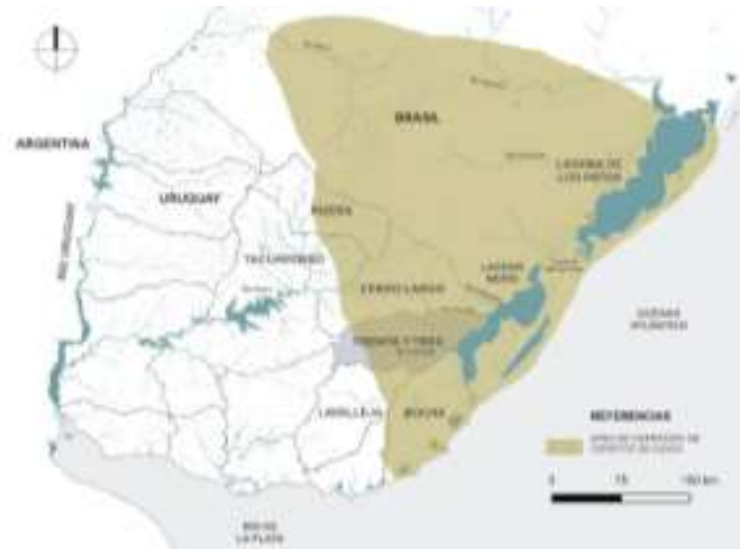

Figura 49. Plano arqueológico, cerritos de indios.

Elaboración propia en base a Los Cerritos de Indios del Este uruguayo. Daniel Vidart, Ediciones de la Banda Oriental. 1999. 
La segunda etapa se considera desde principios del Siglo XVII hasta principios del Siglo XX. La introducción de la ganadería en 1611, transforma el territorio, produce cambios en la pradera, altera flora y fauna local, y el modo de vida de los aborígenes. Con la introducción del caballo, las distancias multiplican las posibilidades de recorrer el territorio. Se define un territorio diferente, aunque difícil de registrar porque los indígenas adoptan la invisibilidad para sobrevivir al conquistador. Hacia fines del siglo XVII, la reproducción del ganado convierte la Banda Oriental en un centro codiciado para la explotación del cuero. Aparecen los primeros signos de estructuración, los puertos y embarcaderos para el traslado del cuero. El río Cebollatí y la Laguna Merim se convirtieron en ruta fluvial de mercaderías hacia Brasil.

A partir de la fundación de Montevideo a principios del Siglo XVIII, el territorio de la Banda Oriental comienza su estructuración formal. La corona española, otorga o vende extensiones de tierra para la explotación ganadera. En ese contexto surge la "estancia cimarrona" una explotación prácticamente sin construcciones, instalaciones, sin personal permanente donde los productos para la subsistencia se encontraban al alcance de la mano, que predominó en el este del territorio hasta fines del XVIII. Posteriormente ese establecimiento informal da lugar a la "estancia", que se transforma en la despoblada campaña, en un núcleo generador de relaciones humanas, centro económico-social y lugar de refugio en un medio inseguro, que junto con las pulperías y capillas dispersas fueron los centros básicos de la sociabilidad rural, en tanto la población urbana se concentraba en ciudades y pueblos cuya creación estaba ligada al control de fronteras con Brasil y hacia fines de Siglo al avance del ferrocarril.

En general, a lo largo de toda la historia uruguaya, el campo se caracterizó por el vacío demográfico y la limitada accesibilidad.

Pero es a partir de la segunda mitad del siglo XIX, fundamentalmente después de 1870 con el alambramiento de los campos que el proceso de consolidación de la propiedad de la tierra comienza a afianzarse y se configura la actual estructura del territorio rural. El estado uruguayo, para cubrir los espacios vacíos, tener una distribución más homogénea de la población, y sobre todo para un efectivo el control de fronteras, encara la fundación de centros poblados en el este del país.

En ese Uruguay del siglo XIX, a partir de la racionalización económica de la ganadería, y el afianzamiento de Montevideo como puerto y capital confluyen nuevos inmigrantes europeos que conjuntamente con los desplazados del campo en esa mezcla de culturas, legados y vivencias darán inicio al país de los uruguayos.
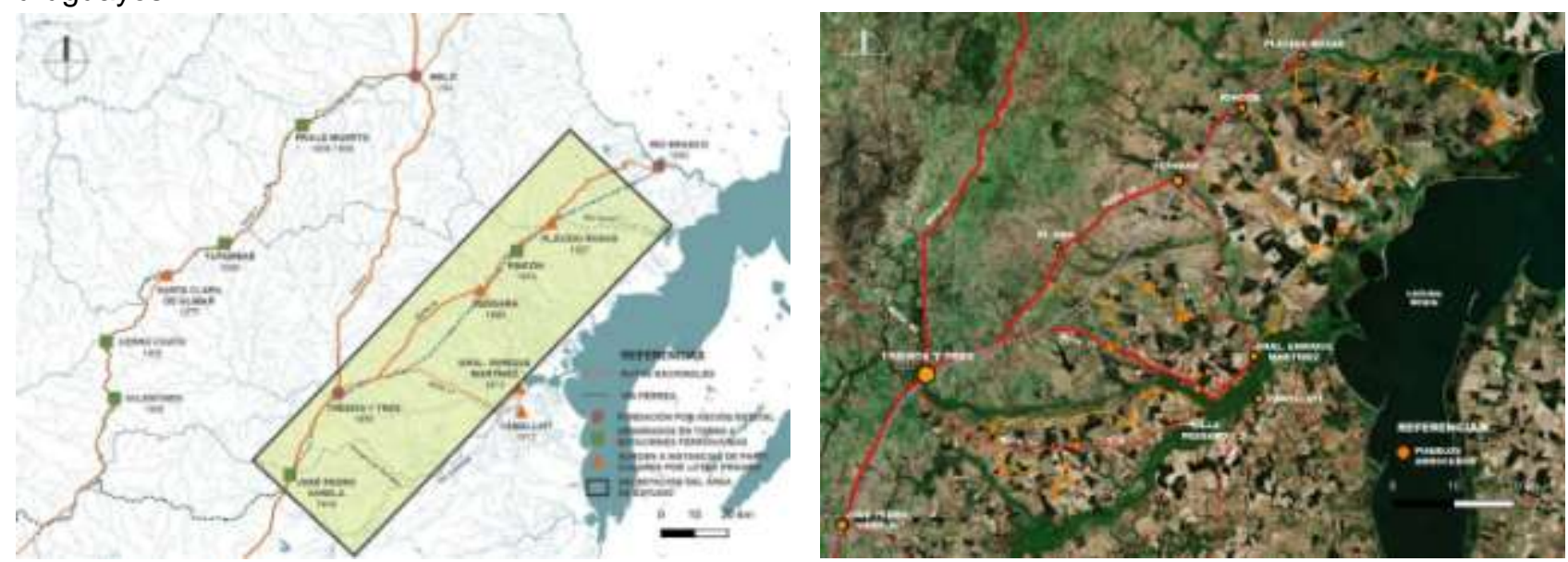

Fundación de centros poblados -

Elaboración propia sobre fuente, Las Ciudades del Uruguay, Carlos Musso (2003)

\section{Constelación de pueblos arroceros.}

Elaboración propia sobre datos de Infraestructura de datos espaciales, conjunto de datos provisorios.

El tercer corte histórico se considera a partir de 1934, cuando se instalan la Compañía Industrializadora de Productos Agropecuarios (CIPA) y Arrozal 33 e instituyen la siembra de arroz a gran escala en el departamento de Treinta y Tres conformando los primeros pueblos arroceros en la Cuenca del Cebollatí.

La instalación del cultivo de arroz, provocó cambios en el paisaje rural incorporando la dimensión urbana y territorial del paisaje antropizado. Se ocuparon nuevos territorios y el establecimiento de la agricultura se constituyó una de las más significativas huellas en el territorio provocando impacto: geográfico, urbanoterritorial, político, económico y social.

Surge un territorio con dos lógicas diferentes, la rural y la urbana. Se pasa de una explotación ganadera extensiva a una explotación agrícola-ganadera. El territorio agrario impregnado de un sentido utilitarista y funcional, vinculado al suelo, clima y a las condiciones naturales del paisaje, desarrolla un sistema de 
asentamientos concebidos para la producción Un territorio hasta entonces poco despoblado y de difícil accesibilidad pasa a ser soporte de una de las actividades productivas más importantes del país.

\subsection{Sistema de ocupación de los pueblos arroceros}

A partir de 1950 comienza el proceso de expansión de los PUEBLOS DEL ARROZ que se inicia con una política que beneficia al sector agropecuario. La nueva red de asentamientos amplía el espacio ocupado e introducen una nueva forma de habitar el campo en la que cada parte está en función de otra en un contexto complejo.

El sistema de ocupación (Montaner, 2008) se establece disperso y se constituye por enclaves que lo estructuran y le dan forma. Cada pieza está relacionada entre sí y con el exterior urbano, no hay ningún objeto aislado, existen relaciones entre los edificios y los espacios comunes que definen.

En estos pueblos se instalan los trabajadores con su familia. Las manifestaciones urbanas en territorio rural productivo se han sucedido en la historia Responden al modelo de "company town" que promueven la concentración de trabajo, viviendas, equipamientos y asumen la función productiva como principal programa. El modelo es adecuado a la explotación agropecuaria e industrial, a la vez que es funcional a los intereses de la empresa.

Los pueblos se disponen en un sistema-red con dinámicas análogas y similares prácticas de ocupación y funcionamiento. En un principio fueron relativamente autónomos. Se construyeron sin proyecto urbano previo ni reglamentación, en tierras privadas, en sitios de fácil accesibilidad, al borde de caminos principales y equidistantes de las tierras de cultivo. En muchos casos se enmarcan por plantíos de eucaliptus como protección y resguardo de vientos predominantes y aporte de leña para el secado del grano.

\subsection{Sistema de asentamiento de los pueblos del arroz}

El surgimiento de nuevas actividades productivas que complementaron una explotación ganadera predominante, dotan al Territorio del este uruguayo de un mayor sentido económico. La implantación de los pueblos, hizo posible la producción arrocera conformando un sistema de asentamientos concebidos con lógicas semejantes estructurados con una fuerte impronta funcional relacionada al manejo del cultivo y a la extracción de agua para riego, dando como resultado una trama urbana vinculada a los caminos y canales de agua. Estas estrategias de ocupación y uso generaron una nueva configuración física donde el territorio dejó su aislamiento y adquierió mayor protagonismo.

Se analizan los patrones de asentamiento reconociendo y aislando los elementos que lo conforman. La forma de los pueblos del arroz son el resultado de la interacción de por lo menos tres variables: el soporte suelo (trazado de calles y de canales de riego), el uso del suelo y la edificación. La forma de la trama urbana o la disposición de los elementos estructurales de los pueblos son básicamente lineales (Arrozal Zapata, Arrozal San Fernando), siendo la vía de circulación el eje vertebrador, aunque en otros casos, se desarrollan sobre una trama radial, apoyada en una red de caminos rurales que parten hacia las tierras de cultivo. (Arrozal 33). El entramado viario es entonces quien determina la estructura urbana, condiciona la disposición de la edificación y el sistema de movimientos.

Los edificios se construyen en tormo a la calle para minimizar los costos de acceso. Por su lógica evidente, han surgido de en contextos diferentes a lo largo de la historia.

Los elementos que forman el patrón son la vía, el parcelario asociado a ésta, los edificios y las centralidades. Los canales de regadío, principales y secundarios, estructuran el territorio rural al igual que las obras de infraestructura conforman un sistema que organiza el paisaje.

La forma y disposición de las construcciones en los pueblos, responde a los usos o actividades que albergan. Predomina la actividad agrícola e industrial y en menor grado se desarrollan algunas actividades terciarias que requieren adecuación tanto de los espacios que alojan las actividades (parcelas y edificios) como de los canales de circulación

La tipología edificatoria adoptada en estos lugares se relacionan con las actividades desarrolladas: viviendas unifamiliares aisladas y en algún caso pabellones habitacionales para solteros, alguna construcción para uso comercial, edificios de oficinas aislados, club social, escuela primaria, iglesia, policlínica, instalaciones industriales, silos para depósitos del cereal, edificios de talleres, almacenes, mantenimiento de maquinarias, etc.

Los pueblos arroceros se transforman en la urbe rural donde se ubica la residencia, los servicios, el equipamiento y el centro de producción y de intercambio, a la vez que estructura el suelo productivo y las relaciones formadas con la naturaleza.

Se identificaron cuatro formas urbanas de ocupación que dependen básicamente de la ubicación relativa al camino principal 

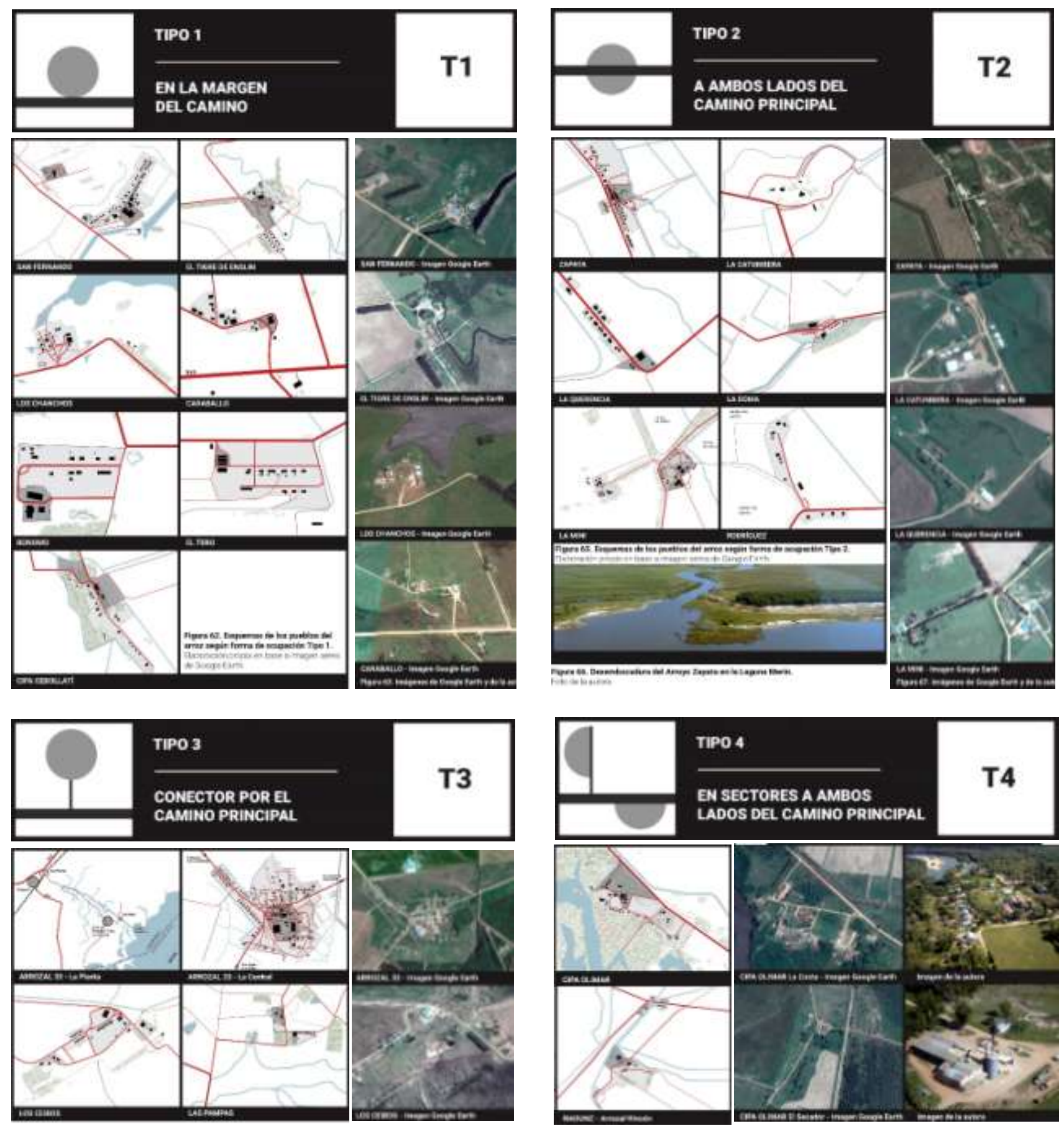

Formas urbanas de ocupación. Elaboración propia sobre imágenes de google earth, imágenes de google earth Imágenes de la autora.

\subsection{Estructura urbana y sus elementos}

El origen de los pueblos se debe a razón económica con una función dominante "la producción de arroz". La población se establece en un territorio ámbito de producción y configura situaciones de localización similares En la mayoría de los pueblos se sigue el mismo patrón de asentamiento y ocupación del territorio. Al comienzo del proceso albergaba a la mayoría de los trabajadores, en la actualidad, al mejorar la caminería, los obreros se trasladan con su familia a centros poblados cercanos y se desplazarse diariamente a los lugares de trabajo.

Si bien la migración campo-ciudad no es un tema nuevo, ni exclusivo de América Latina, en el Uruguay actual, un país con una estructura productiva vinculada a la tierra, se sigue verificando el "éxodo rural"

Las instalaciones y las edificaciones de los pueblos arroceros, conforman un sistema, dentro de un sistema mayor que actúa como contexto. Para entender el sistema de ocupación es necesario conocer los elementos que intervienen en el conjunto y comprender la conexión entre ellos. 
La composición se limita a la ordenación de viviendas y demás edificios dispuestos de acuerdo a una lógica funcional.

Si bien no se encontraron demasiadas fuentes documentales del proceso de construcción se localizaron algunos planos del conjunto de los edificios que constituyeron la documentación de referencia al igual que fotografías de uso empresarial y otras tomadas por técnicos y trabajadores.

En los primeros emprendimientos las instalaciones para el molino, depósitos fueron sustanciales. Las construcciones se articulaban en un estricto orden funcional, los nexos internos solamente fueron constituidos por vías donde predominaban las líneas de circulación que siguieron reglas internas, de tal manera que los itinerarios peatonales no se cruzaban.

Para los silos y galpones se usaron elementos estandarizados, cuya decisión se explica por la reducción en proyectos y construcción de la obra.

Las instalaciones del secador componen un conjunto de construcciones que permiten el secado del arroz que una vez enfriado, es depositado en los silos de almacenamiento para luego ser trasladado al molino. En la mayoría de los casos fueron prefabricados en chapa.

Los edificios para talleres, administrativos y las instalaciones de apoyo a la producción fueron construidos de manera utilitaria.

Las viviendas se resolvieron a través de tipologías diferentes: individuales, apareadas o agrupadas y también algunas versiones de viviendas colectivas lineal con baños comunes como el caso de Arrozal 33 y CIPA Olimar).Se recurre a la repetición de elementos de fácil disponibilidad y bajo costo, en construcciones estándar.

En el comienzo, las viviendas de los trabajadores se resolvieron de "fajina" y adobe con techo de paja,(en Arrozal 33 quedan todavía algunos ejemplos en pie), pero más tarde al deteriorarse y pensar en su sustitución, en las paredes, se emplean materiales más duraderos como bloque de hormigón, ladrillos o ticholos y en la cubierta superior, techo de dolmenit o chapa con cielorraso de paja, un recurso disponible en la zona de bañados.

Para los espacios abiertos de uso colectivo, se destinaron áreas centrales: la plaza, un lugar tranquilo con algo de equipamiento, árboles bancos y en algunos casos juegos infantiles y la cancha, un lugar más amplio, escenario de competencias. En algunos pueblos se constató la existencia de un edificio de uso colectivo, club, salón comunal, quincho, para el desarrollo de reuniones y eventos.
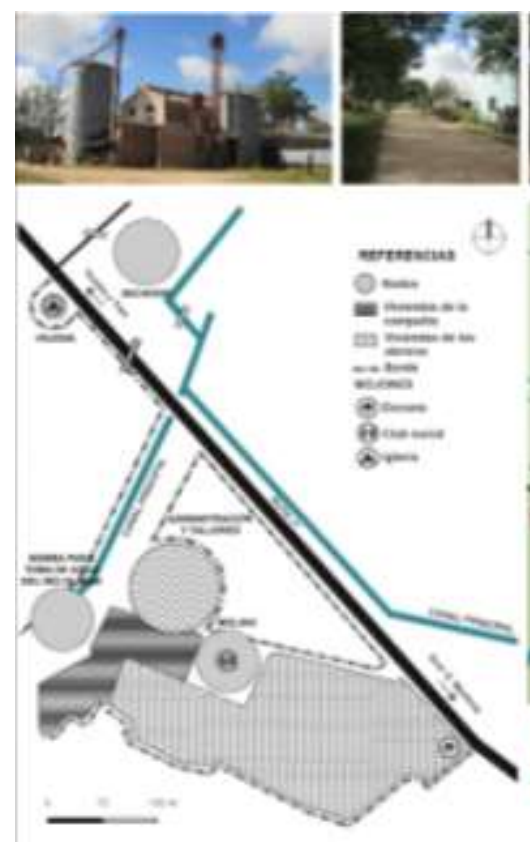

CIPA OLIMAR. Usos del Suelo y Esquema morfológico Elaboración propia. Fotos de la autora
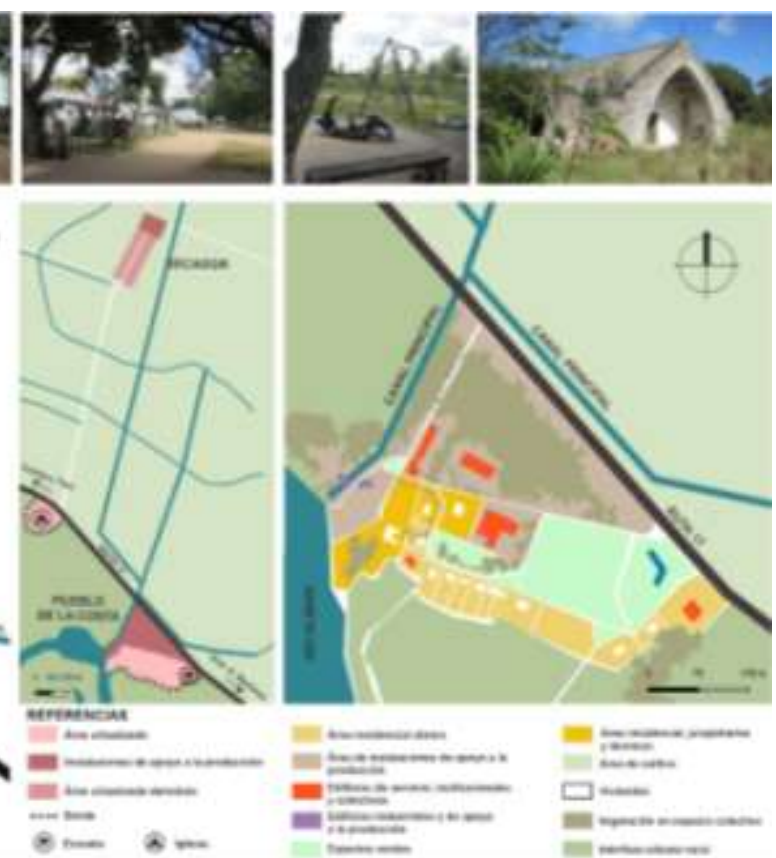


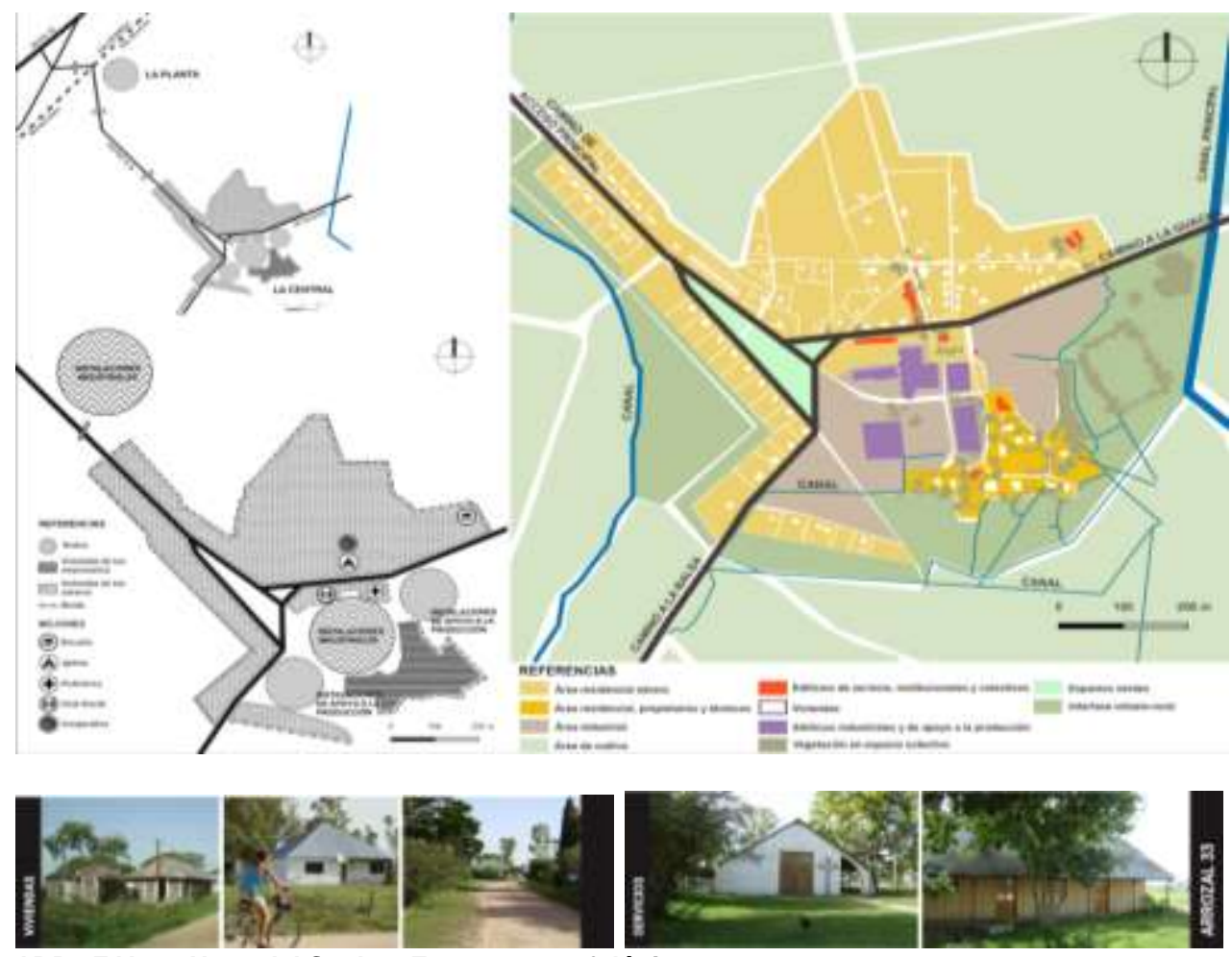

ARROZAL 33 Usos del Suelo y Esquema morfológico

Elaboración propia Fotos de la autora
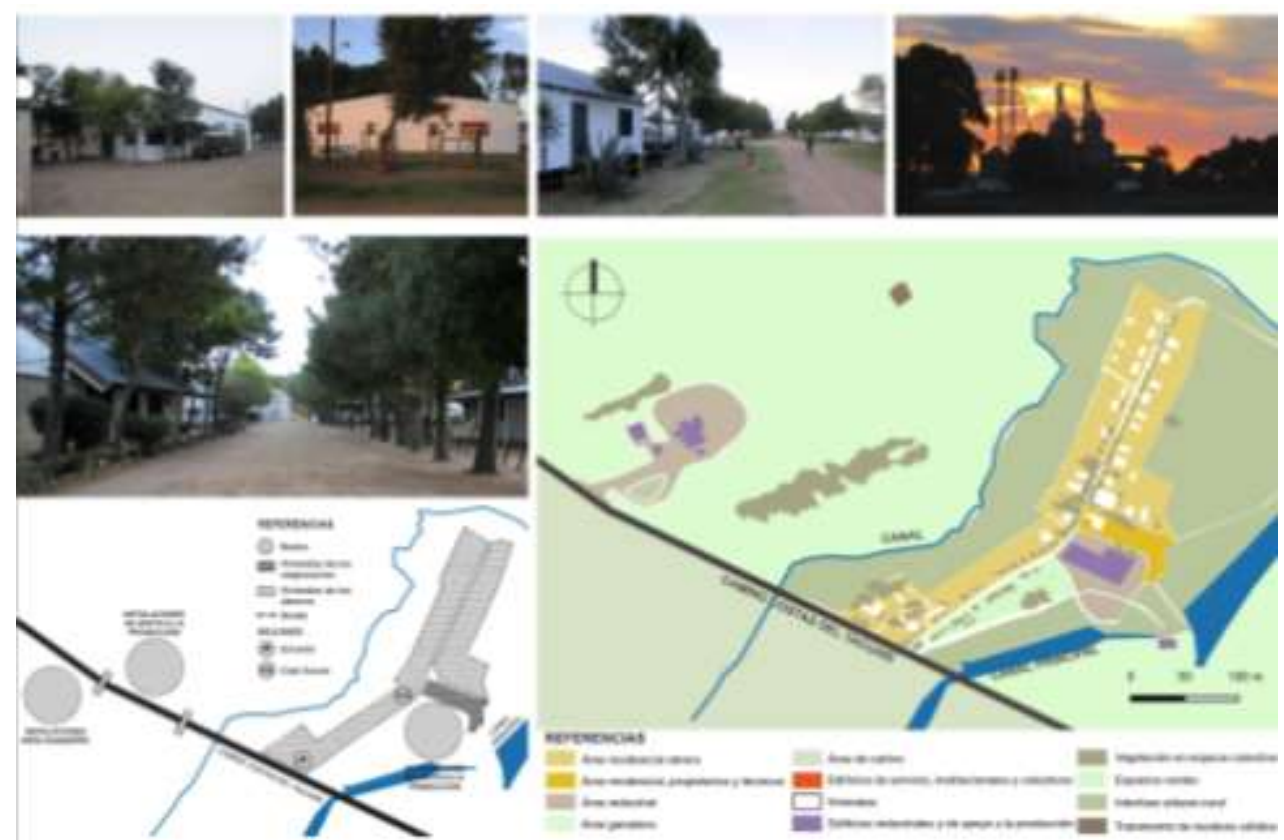

Arrozal SAN FERNANDO Usos del Suelo y Esquema morfológico

Elaboración propia. Fotos de la autora 


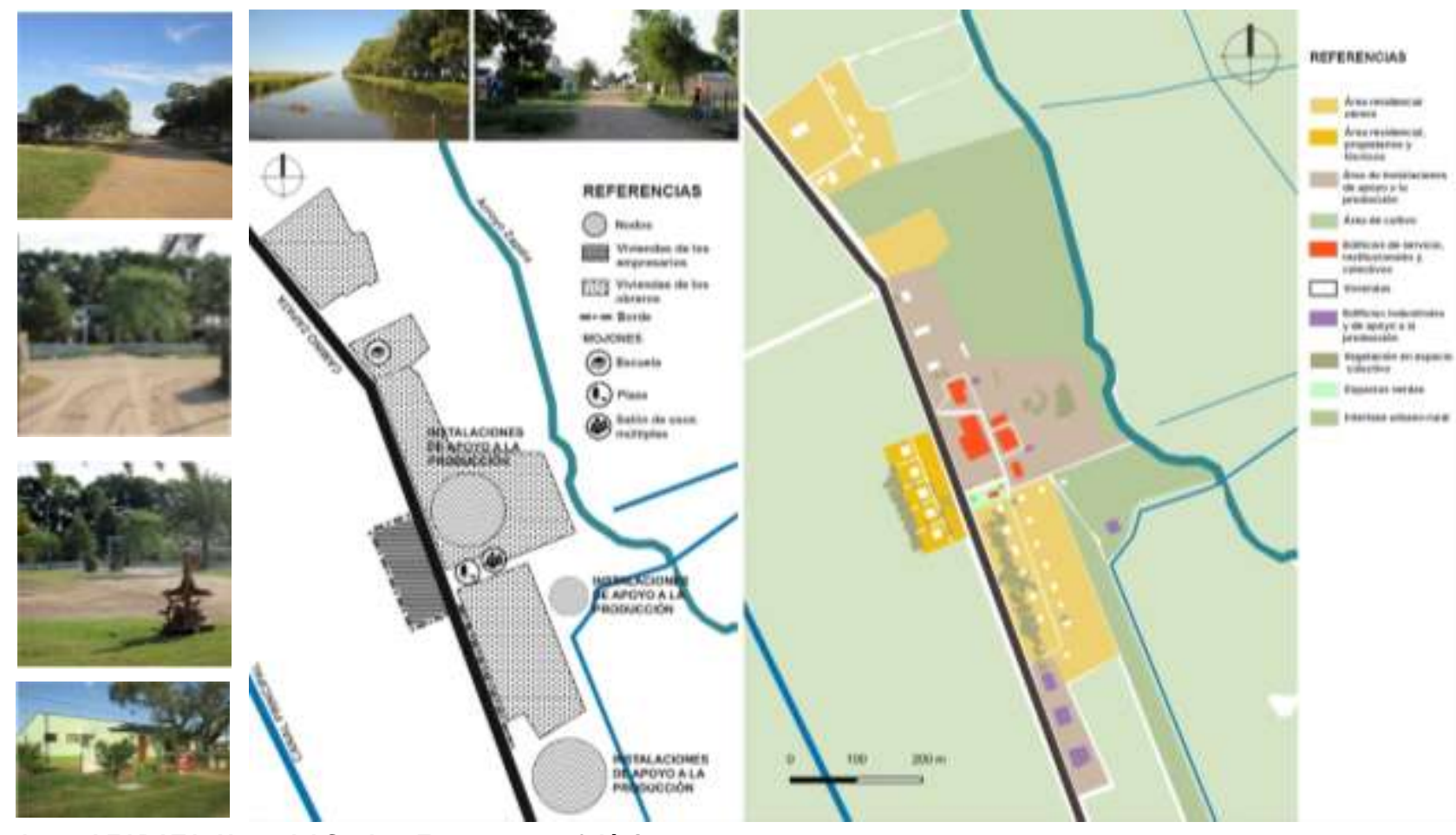

Arrozal ZAPATA Usos del Suelo y Esquema morfológico

Elaboración propia. Fotos de la autora

Tanto la escuela como la iglesia, son edificios con fuerte impronta territorial.

La escuela juega un rol muy importante, se nutre del entorno circundante y forma parte de la cultura del lugar. Como agente socializador pretende compensar las desigualdades con respecto al contexto urbano. No en todos los pueblos hay escuelas, pero donde las hay, se constata una ubicación periférica. Se localiza al borde de los caminos principales, alejado de las instalaciones industriales, depósitos y flujo de tránsito productivo. Son edificios emblemáticos por su función, sin embargo el resultado formal no siempre lo evidencia. Por lo general son construcciones existentes adaptadas, aunque hay también edificios nuevos, cedidos al estado, que es quien se ocupa del funcionamiento. El programa educativo no siempre es el mismo, aunque se verifica que cuenta con diversos espacios y la casa habitación para el docente. El acceso a la escuela se realiza a través de un espacio, patio o plaza interna que oficia de muelle entre el edificio escolar y las vías de tránsito intenso. Los ejemplos de los gráficos dan testimonio de su ubicación con respecto a las vías de conexión, ya que no solo concurren niños de los pueblos sino del área rural de influencia.

La Capilla religiosa es un sitio de referencia destacado, simboliza no solamente el centro de la unidad religiosa sino la base de la unidad social. La Iglesia actúa como un agente urbanizador, insertándose en las formas de vida de los habitantes y perfilando el pueblo. No es solo una construcción material y objetiva sino que aporta significado. Se trata de un edificio representativo concebido espacialmente para su función; lugar de encuentro y desarrollo específico de experiencias. Las dos primeras empresas agroindustriales ubicadas en la zona, le otorgaron a la iglesia una ubicación destacada en el conjunto. En el caso de CIPA Olimar se sitúa en el baricentro de los dos pueblos: El Secador y La Costa y en el caso de Arrozal 33 contigua a las zonas de obreros, técnicos e industrial. Si bien en ninguno de los dos casos tuvieron párrocos permanentes, los establecidos en localidades cercanas oficiaron misa por lo menos con frecuencia semanal.

Como en general, los servicios de policlínica no son permanentes, se adecúa un local polifuncional que sirve para ese propósito.

\section{SINTESIS}

Este trabajo en sus sucesivas aproximaciones nos ha permitido interpretar y poner en valor el paisaje del trabajo, comprender la relación entre el nivel natural del área y sus habitantes.

En la Cuenca Baja del Cebollatí, un territorio de la interfase Uruguay-Brasil, una zona donde se mezclan usos, costumbres, valores y expresiones idiomáticas donde se formaron identidades propias, nos encontramos con una ocupación del espacio que consolida áreas productivas, naturales y urbanas características y produce manifestaciones territoriales-urbanas significativas. 
La organización del territorio expresa su forma de conquistarlo, presenta un orden relacionado a las condiciones requeridas por el cultivo de arroz, conformando un sistema agrícola particular que aprovecha al máximo los recursos naturales y materiales conformando un espacio urbano-rural integrado. Esta nueva estructuración configura elementos de identidad que establecen un paisaje diferente.

En términos de interpretación, se constata la valoración y la exigencia de calidad ambiental en un paisaje que individualiza las transformaciones sociales, la modificación de los modos de producción, las formas urbanas, modos de vida, actividad laboral y económica y sobre todo la visión del mundo y de la vida.

Al explicar e interpretar el territorio, los potenciales naturales y culturales son oportunidades para poner en valor y contribuir a su sustentabilidad. La identificación del medio ambiente, la estructuración del entorno y la búsqueda de raíces en el pasado constituyen la base para precisar la imagen del territorio, una imagen impregnada de recuerdos y significados.

Considerando que el paisaje cultural del arroz y los pueblos arroceros tienen valores que permiten abordar un proyecto territorial basado en el "binomio naturaleza-cultura" (Sabaté, 2009), el territorio de la cuenca Baja del Cebollatí se transforma en una oportunidad. Sin embargo, con la finalidad de promover el desarrollo local estrechando vínculos entre turismo y paisaje, se plantean desafíos, relacionados al involucramiento del sector privado, actores locales y administraciones departamentales con el objetivo de articular mecanismos de participación y traducirlos en instrumentos de planeamiento y gestión sustentables.

Desde la perspectiva territorial, los poblados arroceros han recibido poca atención. En el marco de la Ley de Ordenamiento Territorial y Desarrollo Sostenible (aprobada en el 2008) y en el legítimo uso de la herramienta Directrices departamentales, (aprobadas en 2013) el gobierno municipal desconoció el fenómeno territorial de la zona arrocera, excluyéndolo por omisión de la categorización de suelo. El territorio ocupado por los pueblos con uso de suelo urbano no consolidado quedó incluido en la categorización de suelo rural. El conocimiento y reconocimiento de las existencias es un requisito básico para el ordenamiento territorial, que nos permite prever la transformación, dicho de otra manera nos faculta a proyectar el territorio.

La agricultura se transformó, en la actividad constructora del paisaje y territorio no como mero soporte, sino como factor básico de transformación. En este sentido los paisajes culturales están llamados a jugar un papel relevante, porque constituyen la expresión de la memoria y de la identidad de la región, son la huella del trabajo sobre el territorio, una conformación sin un proceso de finalización, un palimpsesto, (Corboz, 1980)

En la actualidad, el sector arrocero, se caracteriza por ser una cadena agroindustrial integrada, que en los últimos años ha demostrado crecimiento. Uruguay posee una excelente reputación a nivel internacional como productor y exportador del grano. El sistema de producción de baja intensidad, en rotaciones con pasturas e integrado con la producción ganadera, sumado a la alta calidad de la semilla, el reducido uso de insecticidas, herbicidas y fertilizantes permiten la sustentabilidad del cultivo de arroz.

Esta realidad productiva, muy propia y característica, que se diferencia dentro de la región y el mundo, es una de las mayores fortalezas del sistema de producción uruguayo. Posibilita el diálogo entre actores que suponen acuerdos para articular con otras alternativas de desarrollo que convivan con el sistema productivo matriz.

En ese escenario, es posible explotar las potencialidades del territorio, profundizando en el conocimiento de lo local, rescatando los valores del pasado para ponerlos en valor promoviendo el turismo cultural como alternativa para el desarrollo local. Sobre la base de que son los residentes los principales recursos, no perder el paisaje heredado, constituirse en la referencia de la memoria histórica de la Cuenca Baja del Cebollatí, como espacio construido, convertirse en un homenaje vivo y permanente a un tiempo, a la sociedad que lo construyó.

Si bien el cultivo no tiene un comportamiento expansivo en su superficie, constituye un sector de captación y aplicación de otros recursos productivos: mano de obra, tecnología del cultivo, inversión en instalaciones, transporte y potencialmente, revalorizando los pueblos, y el entorno natural en el cual se inscribe, se pondría en funcionamiento el sistema territorial con un nuevo enfoque a favor del territorio y el desarrollo sostenible.

Es importante relacionar los recursos culturales a partir de una idea fuerza territorial, dotarlos de estructura a través de una hipótesis de interpretación avanzando en cuanto a criterios de ordenamiento territorial con la finalidad de lograr una gestión coherente de esos recursos. Se intenta que a partir de la selección y 
discusión de una serie de episodios y proyectos significativos, descubrir el potencial de la nueva aproximación desde la perspectiva de la disciplina urbanística.

Se logró avanzar en el conocimiento de lo local, conocer este patrimonio nos abre las puertas no solo a la difusión del conocimiento sino a la valoración del legado histórico cultural que marcará la identidad a futuro. Para su preservación y su posible utilización, debe pensarse como una huella, eje del sistema que cambió por completo el orden territorial, testimonio de valores sociales y culturales.

\section{BIBLIOGRAFÍA PRINCIPAL}

CUENCA DEL CEBOLLATÍ...nuestro territorio....un proyecto compartido. (2009).

Maestrandos de la Maestría de Ordenamiento Territorial y Desarrollo Urbano. Montevideo, Uruguay: FADU UdelaR. Convenio UdelaR - Intendencias de Treinta y Tres, Lavalleja y Rocha.

EIZAGUIRRE, X. (1990). Los componentes formales del territorio rural. Los modelos de estructuras agrarias en el espacio metropolitano de Barcelona. La Masía como modelo de colonización en Torelló. Barcelona, España: Tesis doctoral de la Universidad Politécnica de Catalunya.

FOLCH, R., \& otros, y. (2003). El territorio como sistema. Conceptos, herramientas y ordenación. Barcelona, España: Edición diputación de Barcelona. ISBN: 84-774-962-X.

GARCÉS FELIÚ, E. (1999). Las ciudades del salitre. Santiago de Chile: Orígenes.

GOROSITO, R., \& LIGRONE, P. (2009). Sistema de ordenamiento territorial y desarrollo sostenible - Ley fundante 18308. Montevideo, Uruguay: La Ley Uruguay.

LYNCH, K. (1960). La imagen de la ciudad. Barcelona, España: Gustavo Gili.

MONTANER, J. (2008). Sistemas arquitectónicos contemporáneos. Barcelona, España: Gustavo Gili.

MUSSO, C. (2004). Las ciudades del Uruguay, su origen, evolución histórica y urbanística en el contexto nacional y macro regional y sus perspectivas de futuro. Montevideo: Universidad de la República

PANARIO, D., \& GUTIERREZ, O. (2011). Introducción a la geomorfología de lagunas costeras, lagos someros y charcas del Uruguay. El holoceno en la costa uruguaya. Montevideo, Uruguay: Colección biblioteca plural de la CSIC. Universidad de la República. ISBN: 978-9974-0-0757-4.

PERE VALL, C. (1999). De Colónies téxtiles a Parc de les Colónies. El sistema de colónies téxtils del Baix Génesi i revaloració. (pp. XIII-XVIII) Associació d'Enginyers Industrials de Catalunya. Barcelona, España: Marcombo S.A. ISBN 84-267-1209-6.

PROBIDES. (abril de 2000). Plan Director de la Reserva de Biósfera de Bañados del Este. Rocha, Uruguay: Bañados del Este - Año 7 - № 17. MVOTMA, IMR, IMMaldonado, IML, IMTYT, IMCL. Financiado por la UE, PNUD, Global Environment Facility. 1999.

REYES ABADIE ; BRUSCHERA; MELOGNO. (1965). Pradera - Frontera - Puerto. Montevideo, Uruguay: Banda Oriental.

SABATÉ BEL, J. (2004). Paisajes culturales. El patrimonio como recurso básico para un nuevo modelo de desarrollo. Revista URBAN, Departamento de Urbanística y Ordenación del Territorio. Escuela Técnica Superior de Arquitectura. Universidad Politécnica de Madrid, 9,8-29.

SABATÉ BEL, J. (2009). El valor estructurante del patrimonio en la transformación del territorio. Apuntes No. 22, 31. Bogotá, Colombia. ISSN 1657-9763. 